\title{
Drivers of SaaS-Adoption - An Empirical Study of Different Application Types
}

Software-as-a-Service (SaaS) has been heralded by IT providers as a serious alternative to on-premises software. However, its acceptance among software using companies has been inconsistent across application types. While some SaaS providers (e. g. Salesforce.com for CRM) were successful in establishing a sustainable business model, others (e. g. SAP with Business ByDesign for ERP) still have difficulties to gain a stronger foothold. To better understand this discrepancy, we empirically examined main drivers and inhibiting factors of SaaS-adoption for different application types. Our analysis shows that social influence, the pre-existing attitude toward SaaS-adoption, adoption uncertainty, and strategic value are the most consistent drivers. Furthermore, our study reveals that company size does not matter in SaaS-adoption.

DOI 10.1007/s12599-009-0068-X

\section{The Authors}

Dr. Alexander Benlian
Prof. Dr. Thomas Hess
Ludwig-Maximilians-
University Munich
Institute for Information
Systems and New Media
Ludwigstr. 28
80539 Munich
Germany
\{benlian | thess\}@bwl.Imu.de

Prof. Dr. Peter Buxmann Technical University of Darmstadt Chair of Information Systems Hochschulstraße 1 64289 Darmstadt Germany buxmann@is.tu-darmstadt.de

Received: 2008-12-01

Accepted: 2009-06-03

Accepted after two revisions by Dr. Ruggaber.

This article is also available in German in print and via http://www.wirtschaftsinformatik.de: Benlian A, Hess T, Buxmann P (2009) Treiber der Adoption SaaS-basierter Anwendungen - Eine empirische Untersuchung auf Basis verschiedener Applikationstypen. WIRTSCHAFTSINFORMATIK. doi: 10.1007/11576-009-0189-3.

\section{Introduction}

On-demand software application delivery models are known since the late 1990s and have come along in many forms and varieties such as Application Service Providing (ASP) or Business Service Providing (BSP). The common denominator of all these concepts is that this kind of demand-driven application sourcing model provides network-based access for users and firms to resources and expertise as well as to an integrated portfolio of complex applications that spans the complete virtual value chain of an enterprise (Buxmann et al. 2008). While discussions on ASP-based outsourcing have become rather silent in recent IS research and management literature mainly due to missing breakthrough success stories, a new acronym, called Software-as-aService (SaaS), has gained ground in the attention span of IS executives and is said to become a fundamental pillar of revenues for IT vendors in the next couple of years (Pettey 2006). Although often discussed as an old wine in new skins concept, SaaS promises to breach last barriers of adoption (Hall 2008). It is predicted that SaaS offers more mature and comprehensive service packages as well as flexible access via easy-to-use Internet interfaces on the customer side (Waters 2005) and the ability to support service-oriented multitenancy and a shared IT infrastructure to reap significant economies of scale on the provider side (Valente and Mitra 2007). Traditionally, the interest in on-demand based sourcing models has been driven by a focus on core competencies, the attractive cost model for customers, the flexibility of choosing between different types of (state-of-the-art) technologies, and the great shortage of necessary IT application skills in many firms (Kern et al. 2002b). Countering these benefits are the acknowledged risks of reliability (how can IT departments ensure that the business can access its applications?), security (how can it guarantee data privacy in line with regulations?), and process dependence (how can it make sure that quality of service is really achieved?) when outsourcing IT applications to a $3^{\text {rd }}$ party (Brandt and Buxmann 2008).

A broad spectrum of application types have been offered as SaaS-applications so far, ranging from Office and Collaboration (e. g. Google Apps) to CRM (e. g. Salesforce.com) and ERP (e. g. SAP's Business ByDesign (Zencke and Eichin 2008)), with mixed results. While some user companies and market researchers already predict the doom and collapse of SaaS (Jung and Bube 2008), others draw a more differentiated picture of the future of SaaS declaring that SaaS-adoption will be more successful in specific application markets than in others (Prehl 2008). Moreover, SaaS is promoted by IT providers to be relevant mainly 
for small- and medium-sized businesses (SMBs) that lack necessary IT capabilities and resources (Lünendonk 2007). Against these assumptions though, first empirical studies have found that large enterprises indeed see considerable opportunities for the application of SaaS in different areas (Benlian and Hess 2009).

Puzzled by these mixed point of views, researchers and practitioners have struggled to determine which side of the discussion will prevail over time. In IS research, most studies on software services have focused so far on technical issues such as the development and maintenance, interoperability, or granularity of services (e. g. Erl 2006; Chung et al. 2003). Only few studies have taken up economic or organizational research aspects on SaaS such as business models (e. g. Nüttgens and Iskender 2008), pricing/negotiating (Choudhary 2007; Ahmed and Paul 2004) or customer/supplier relationships (Pearl 2004). One of the many aspects so far neglected on the SaaS research agenda is the investigation of inhibitors and drivers of SaaSadoption (Rai and Sambamurthy 2006). While many research papers have theoretically explored the meaning, characteristics, and economic implications of on-demand software application sourcing (e. g. Walsh 2003; Seltsikas and Currie 2002; Kishore et al. 2001), there is virtually no coverage of the drivers of SaaSadoption on a substantial empirical basis (Smith and Kumar 2004; Ma et al. 2005; Peterson and Fairchild 2003). Although empirical studies of different samples have investigated SaaS-adoption from a transaction cost theoretical lens in small-tomedium-sized and large companies (Benlian and Hess 2009; Benlian 2009), there is still a paucity of research into aspects motivating or inhibiting SaaS-adoption other than transaction cost factors. Specifically, what is missing in the existing literature is a solid research model on the drivers of SaaS-adoption which is informed by multiple theoretical lenses and assessed based on scientific rigor and a broad dataset instead of a few isolated cases.

Our study seeks to address this research gap. Key research goal of our study is to contribute to a heightened understanding of the drivers behind SaaS-adoption viewed through multiple theoretical lenses. Concrete research questions are:

(1) What are the drivers behind SaaSadoption for different application types? Are there different patterns how poten- tial user companies decide on SaaS-adoption?

(2) What is the role of firm size in the adoption of SaaS-based sourcing models? Are SMBs more likely to adopt SaaS than large enterprises irrespective of the application type?

In order to address these relevant research questions, we will shed light on the adoption of SaaS from three theoretical perspectives with the aim to substantiate sourcing decisions of user companies. Chapter 3 presents our research methodology which is followed by the results of our empirical analysis in chapter 4. Chapter 5 concludes with a discussion of findings, practical contributions for user companies and IT vendors, limitations, and future research.

\section{The adoption of SaaS from three theoretical perspectives}

IT outsourcing and adoption behavior of firms have been investigated based on various theoretical foundations in IS research so far. In recent literature analyses of major IS conferences and journal papers (Gonzalez et al. 2006; Wiener 2006; Dibbern et al. 2004), it was found that researchers drew on a multitude of economic, strategic, and social theories to explain IS outsourcing decisions of which transaction cost theoretical and resource-oriented thinking were most often used and also yielded the most consistent results across the various research studies. Taking these approved theories, the objective of this research study is to explain whether and why companies outsource different application types in a SaaS-setting, or, to put it differently, whether and why they adopt SaaS as on-demand sourcing option for specific application types. Since the influence of third-parties (such as experts or associations) regarding the decision-making on this rather immature technology seems to be an important factor in the early stages of SaaS diffusion, the transaction cost theory and the resource-based view will be complemented by the theory of planned behavior in the explanation of SaaS-adoption. The theory of planned behavior not only captures these kinds of peer pressure effects from outside the company, but also shows how the attitude of influential decision-makers within companies affect the final outsourcing decision. Diffusion theory (Rogers 1962) or technology accep- tance models (Davis 1989) are neglected in this study for two reasons. First, this study explicitly seeks to apply a multi-theoretical approach to explain SaaS-adoption that is based on theories that have been validated many times in previous IT outsourcing literature (Dibbern et al. 2004). Second, taking an outsourcing (decision) rather than a diffusion or acceptance perspective is, in the eyes of the authors, closer to the day-to-day decisions of IS executives and thus yields a higher level of practical relevance.

\subsection{Transaction-cost theory and SaaS- adoption}

Transaction cost theory (TCT) is embedded in the framework of the new institutional economics which was first introduced by Coase, who analyzed why firms exist, what determines the number of firms and what firms do. One of Coase's initial propositions was that firms and markets are alternative governance structures differing in their transaction costs (Coase 1937, p. 389) where transaction costs were referred to by Arrow as the "costs of running the system" (Arrow 1969, p. 48). Accordingly, the transactioncost approach is based on the premise that the existence of different organizational forms, whether they are markets, bureaucracies, or clans, is primarily determined by how efficiently each form can mediate exchange transactions between parties (Ouchi 1980). Over the past four decades, Williamson has added considerable precision to Coase's general argument by identifying the types of exchanges that are more appropriately conducted within firm boundaries than via the market. To evaluate different governance or exchange arrangements, Williamson introduced characteristics or determinants of transaction cost differences of which asset specificity and uncertainty turned out to be the most important ones in explaining outsourcing behavior (Williamson 1985). Traditional transaction cost economics posit that transactions with high asset specificity are managed less expensively in-house, while the rest should be outsourced for better efficiency (Williamson 1991). Specifically, the theory suggests that when asset specificity is high, the activities or resources involved in the transaction are so idiosyncratic and customized that insourcing will bear lower overall transaction costs than outsourcing. A number of 
Building Global Leaders

Die Wirtschaft bewegt die IT bewegt die Wirtschaft bewegt die IT bewegt die Wirtschaft ...

\section{0}

„Wechselwirkungen“ - der McKinsey-Workshop für das Zusammenspiel von Wirtschaft und IT. Für Naturwissenschaftler, Mathematiker und Informatiker. Vom 26. bis 29. November in Kitzbühel.

Erfahren Sie praxisnah, wie McKinsey Unternehmen, Institutionen und Individuen dabei unterstützt, komplexe Aufgabenstellungen an der Schnittstelle von Business und Technologie zu lösen. Gewinnen Sie dabei Einblicke in die vielfältigen Tätigkeitsfelder des „Business Technology Office“ und informieren Sie sich über Ihre persönlichen Karrieremöglichkeiten bei McKinsey. Bewerben Sie sich bis zum 11. Oktober 2009 unter www.wechselwirkungen.mckinsey.de

\section{McKinsey\&Company}


prior research studies on IT outsourcing have employed asset specificity in their research models to explain outsourcing decisions with rather puzzling outcomes. While Nam et al. did not find any significant link between asset specificity and outsourcing (Nam et al. 1996), Aubert et al. discovered inconsistent effects of asset specificity (Aubert et al. 2004). On the other end, Dibbern could show that insourcing is more cost efficient and advantageous in creating strategic benefits through IS if the provision of application services requires a high amount of firm specific human assets (Dibbern et al. 2005). Benlian and Hess found that application specificity is the most important driver of adopting applications in a SaaS-based arrangement (Benlian and Hess 2009). In the case of SaaS-based application sourcing, asset or application specificity is reflected in the degree that specific applications can be customized, integrated, and modularized prior to and in the outsourcing relationship. Based on TCT thinking, it can be argued that the higher the degree of application specificity, the lower the level of outsourcing, as integration and coordination costs of running a highly customized application system on the IT provider side outweigh the transaction costs of running the application in-house. To put it differently, highly specific applications involving specific company processes and firm data need complex monitoring, motivation, and coordination mechanisms that are established more efficiently in-house than by outsourcing (Picot et al. 2005). These theoretical assertions lead to the following hypothesis:

H1: Application specificity is negatively associated with SaaS-adoption

Analogous to asset specificity, uncertainty in an outsourcing relationship can be an inhibiting factor (Blumenberg et al. 2008) negatively affecting the degree of outsourcing (Williamson 1991). By the majority, prior research on IT outsourcing has supported this theoretical proposition. For instance, Nam et al. found that uncertainty played a significant role in the decision to outsource. As expected, higher uncertainty led to less outsourcing (Nam et al. 1996). Similarly, Aubert et al. found in their study that the level of uncertainty is the major deterrent to outsource IT operation activities (Aubert et al. 2004). Derived from Williamson's fundamental propositions (Williamson 1985),
Dibbern conceptualizes environmental uncertainty in the IT outsourcing context as a combination of business driven and technology driven uncertainty (Dibbern 2004, pp. 53-54). While business driven uncertainty refers to the extent to which the development of business related issues (such as pricing, processes, and service levels) change over time prior to and in the outsourcing relationship, technology driven uncertainty captures the extent to which the required technical functions or features of the outsourced application change over time. Based on these notions of uncertainty, one can hypothesize for SaaS-based application outsourcing that when business and technology driven uncertainty is high, contracts cannot be clearly enforced and monitored for effective outsourcing by the outsourcer, inducing him to prefer internal governance for highly uncertain activities. This leads us to the following hypothesis:

H2: Adoption uncertainty is negatively associated with SaaS-adoption.

\subsection{Resource-based view and SaaS- adoption}

During the last twenty years, scholars have developed a resource-based framework for analyzing business strategy. Drawing heavily on Penrose's seminal work (Penrose 1959), the resource-based view (RBV) suggests that firms can be conceptualized as a bundle of resources or capabilities that are heterogeneously distributed across firms enabling it to successfully compete against other firms (e. g. Wernerfelt 1984; Barney 1991). According to the RBV, the sources of a sustained competitive advantage are inevitably linked to an organization's base of resources. An organization can only differentiate itself from current and potential competitors if some of its resources are valuable, rare, inimitable, and non-substitutable resulting in a unique strategic value (e. g. Barney 1991; Peteraf 1993). These resources can either be physical, such as unique equipment or IT hardware, or intangible, such as brand equity, operating routines, or IT software. In the early 1980s, researchers began to conceptually analyze how IT/ IS can impact the competitive position of firms. Porter and Millar have been among the first to argue that the deployment of IT would enable firms to both lower costs and enhance differentiation by either serving as performance driver or enabler of new business ventures (Porter and Millar 1985, p. 150). More recently, researchers tend to emphasize the complementary and supporting role of IS in generating a sustained competitive advantage (e. g. Clemons and Row 1991).

In this study, we argue that IT applications will be outsourced (in a SaaS-mode) in dependence of the degree of strategic value that companies attach to their applications. The more applications support critical process steps and functions of organizations, the more companies will tend to keep these core resources in-house, since they try to avoid running the risk of losing control or access to their applications (including functions and data). On the other hand, companies will be more likely to outsource applications with lower strategic value, since opportunity costs of loosing access to these applications are lower as they do not support critical functions. We thus derive the following hypothesis:

H3: The application's strategic value is negatively associated with SaaS-adoption.

In the same regard, we argue that companies will increasingly refrain from outsourcing IT applications if these applications represent indispensable and nonsubstitutable factors in the core processes of companies enabling them to gain competitive advantages. Companies will therefore be more likely to outsource highly imitable applications, since they can be substituted more easily by other applications or even manual work. We therefore derive the following hypothesis.

H4: The application's inimitability is negatively associated with SaaS-adoption.

\subsection{The theory of planned behavior and SaaS-adoption}

The theory of planned behavior aims to predict and explain the behavior of individuals (Ajzen 1991). It is used as additional explanatory lens in this study, since IT sourcing and adoption are management decisions performed by individuals rather than by organizations (Dibbern 2004). During the process of evaluating alternative sourcing options, IS executives are influenced by their social environment, either deliberately or unintendedly. More specifically, the cognitive process guiding individual decision making is subject to the individual's perceptions of his/ her social 
environment. In this context, behavior may be characterized by "... behavioral criteria (...) comprised of four elements: the action, the target at which the action is directed, the context in which it occurs, and the time at which it is performed" (Ajzen and Fishbein 1980, p. 39). Applied to this study, the action is the adoption or non-adoption of SaaS directed at the target of different application types within the context of user organizations. Moreover, it is supposed that the action will take place in the future (time) reflected by an organization's planned degree of SaaSadoption. According to the theory of planned behavior, the choice in favor of or against a certain option depends on an individual's intention to perform a certain action which, again, is influenced by two main factors: the attitude towards the behavior and the subjective norm. Attitude toward SaaS-adoption can be defined as the overall evaluative appraisal of an IS executive toward having an IT application provided by a SaaS-provider. Subjective norm or social influence denote “(...) the perceived social pressure to perform or not perform the behavior", which is "influenced by normative beliefs which are concerned with the likelihood that important referent individuals or groups approve or disapprove of performing a given behavior" (Ajzen 1991, p. 195).

In the theory of planned behavior, the attitude toward the behavior is hypothesized to influence the actual behavior (i. e. SaaS-adoption), as it integrates different salient beliefs about the outcome expectations of the decision options. A decision-maker on SaaS-adoption thus forms an attitude based on beliefs about factors such as the potential diffusion of this technology in the market, cost-benefit evaluations, or performance implications of this technology on processes. A lot of prior studies have investigated the impact of such major beliefs associated with the IT outsourcing choice on the attitude toward IT outsourcing (e. g. Dibbern 2004). Major beliefs that are of interest in this study have already been deduced from transaction cost theory and resource-based theory comprising the four factors on beliefs about application characteristics. More specifically, attitude toward SaaS-adoption acts as mediator or intervening factor between application characteristics and SaaS-adoption. We thus derive the following hypotheses:

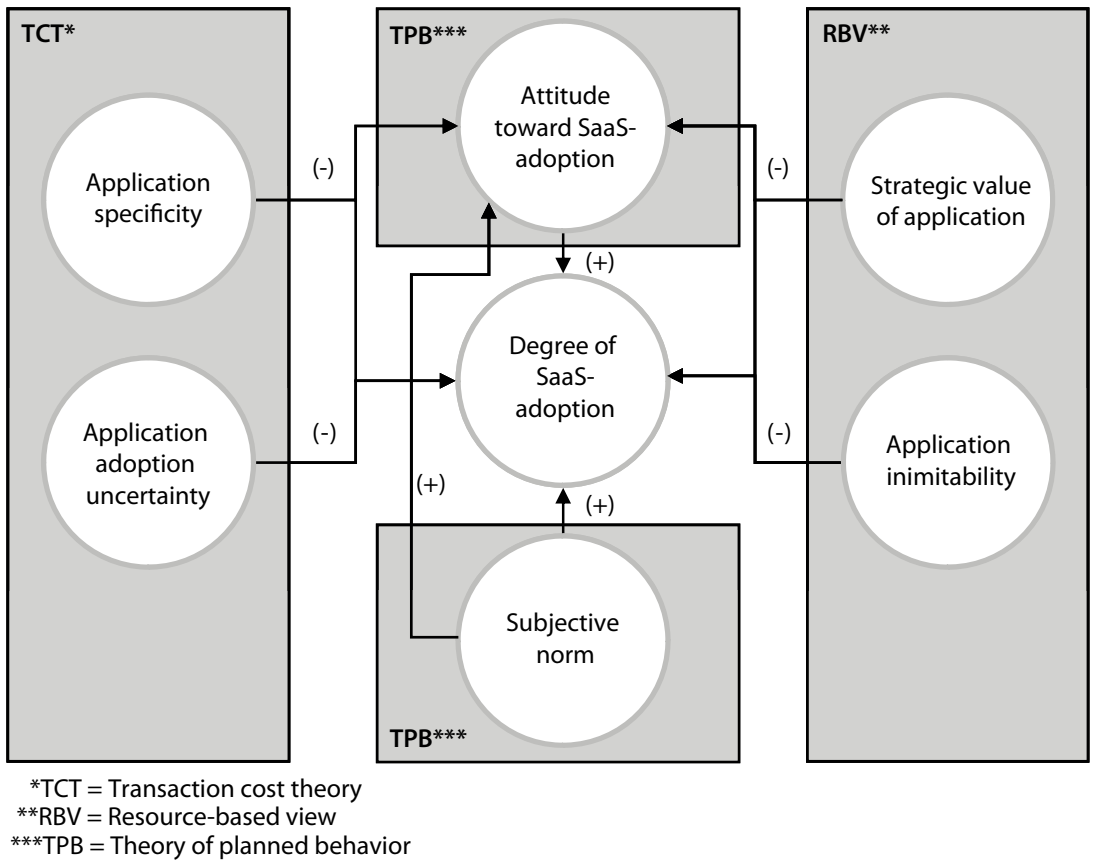

Fig. 1 A multi-theoretical research model on SaaS-adoption

H5: Application specificity is negatively associated with attitude toward SaaSadoption.

H6: Adoption uncertainty is negatively associated with attitude toward SaaSadoption.

H7: Strategic value is negatively associated with attitude toward SaaS-adoption.

H8: Application inimitability is negatively associated with attitude toward SaaS-adoption.

H9: Attitude toward SaaS-adoption is positively associated with SaaS-adoption.

Previous research on IT outsourcing found that an organization's sourcing and adoption decisions may not always result from an evaluation and comparison of alternative sourcing options. For example, it could be found that organizations sometimes exhibit herd-like behavior in the outsourcing of IT, imitating the behavior of other organizations without rationally thinking through the alternatives and consequences (Lacity and Hirschheim 1995). In this regard, a decision maker's adoption appraisal of new and immature technological phenomena such as SaaS can be considered as being heavily influenced by third party opinions. In particular, market research firms, IT consultants, SaaS providers, and IT associations try to provide their own answer ("market-making") as substitution for the lack of experience with SaaS. It can thus be argued that the more positive the opinion of influential others toward SaaS-adoption, the higher will be the rate of SaaS-adoption. Based on these theoretical notions and previous empirical results, the following hypothesis is put forth:

H10: Subjective norm (i. e. positive opinion of influential others toward SaaS) is positively associated with SaaS-adoption.

Finally, in the same way as application characteristics may influence the attitude toward SaaS-adoption, it can be hypothesized that the social influence of thirdparties (subjective norm) affect the attitude toward SaaS-adoption. That is, if experts or market researchers draw a positive picture on SaaS-adoption, decisionmakers of user companies will more likely form a favorable attitude to SaaS-adoption on their own.

H11: Subjective norm is positively associated with attitude toward SaaS-adoption.

Drawing upon the empirical evidence and theoretical perspectives provided above, we seek to fill this research gap by examining factors explaining SaaS-adoption. Fig. 1 illustrates all hypotheses in our research model. 


\begin{tabular}{|c|c|c|}
\hline $\begin{array}{l}\text { Constructs (Measurement } \\
\text { model) }\end{array}$ & Indicators & Source \\
\hline \multirow[t]{2}{*}{ SaaS-adoption (reflective) } & Overall level of SaaS-Adoption with respect to the application in 2008 and 2010 & $\begin{array}{l}\text { Loh 1994; Loh and } \\
\text { Venkatraman } 1995\end{array}$ \\
\hline & $\begin{array}{l}\text { Approximate/ Estimated percentage of the application's IT budget } \\
\text { allocated to SaaS-based outsourcing in } 2008 \text { and } 2010\end{array}$ & Dibbern 2004; Teng et al. 1995 \\
\hline \multirow{4}{*}{$\begin{array}{l}\text { Attitude toward } \\
\text { SaaS-adoption (reflective) }\end{array}$} & Overall, using the application in a SaaS-based relationship is & \multirow{4}{*}{$\begin{array}{l}\text { Dibbern 2004; Ajzen } \\
\text { and Fishbein } 1980\end{array}$} \\
\hline & (...) negative-positive & \\
\hline & (...) harmful-beneficial & \\
\hline & (...) unimportant-important & \\
\hline \multirow[t]{4}{*}{ Subjective norm (reflective) } & $\begin{array}{l}\text { Persons or groups whose opinion is important to our organization } \\
\text { think that using this application in a SaaS-based relationship is }\end{array}$ & \multirow[t]{4}{*}{$\begin{array}{l}\text { Dibbern et al. 2004; Ajzen } \\
\text { and Fishbein } 1980\end{array}$} \\
\hline & (...) negative-positive & \\
\hline & (...) harmful-beneficial & \\
\hline & (...) unimportant-important & \\
\hline \multirow{3}{*}{$\begin{array}{l}\text { Application specificity } \\
\text { (reflective) }\end{array}$} & The extent to which the application architecture is modular (reverse coded) & \multirow[t]{3}{*}{ Kern et al. 2002a } \\
\hline & The extent to which the application is customized & \\
\hline & The extent to which the application is integrated into the overall application landscape & \\
\hline \multirow[t]{3}{*}{$\begin{array}{l}\text { Perceived uncertainty } \\
\text { (reflective) }\end{array}$} & $\begin{array}{l}\text { The extent to which the application outsourcing is subject to } \\
\text { technical difficulties in terms of bandwidth and reliability }\end{array}$ & \multirow[t]{3}{*}{$\begin{array}{l}\text { Smith and Kumar 2004; } \\
\text { Ma et al. } 2005\end{array}$} \\
\hline & $\begin{array}{l}\text { The extent to which the application outsourcing is subject to } \\
\text { economic dependencies in terms of pricing model changes }\end{array}$ & \\
\hline & $\begin{array}{l}\text { The extent to which the application outsourcing is subject to process } \\
\text { dependencies in terms of quality of service provisioning (e. g. in SLAs) }\end{array}$ & \\
\hline \multirow[t]{3}{*}{ Strategic value (reflective) } & The application has critical strategic importance for our company & \multirow[t]{3}{*}{ Barney 1991} \\
\hline & The application contributes largely to our company goals & \\
\hline & The lack of this application would lead to competitive disadvantages & \\
\hline \multirow{3}{*}{$\begin{array}{l}\text { Application inimitability } \\
\text { (reflective) }\end{array}$} & The application is a company resource that can't be substituted & \multirow[t]{3}{*}{ Barney 1991} \\
\hline & The application has company-specific configurations that can't be provided by third-parties & \\
\hline & The configurations of the application is very different from those of competitors & \\
\hline
\end{tabular}

\section{Research methodology}

\subsection{Survey administration and sample characteristics}

To test the research model in Fig. 1 and the associated hypotheses suggested above, we designed a questionnaire and conducted a survey based on a random sample of 5.000 German companies drawn from the Hoppenstedt database (http://www. hoppenstedt.com). To support external validity of our study, we did not constrain the sample to specific industries or firms of specific organizational size. The survey questionnaire was designed on the basis of a comprehensive literature review in the IT adoption and outsourcing context and based on interviews with IT managers. After several rounds of pretests and revisions, the survey was sent by mail and e-mail to the companies in the sample in July 2008. The survey was conducted at the application type level, so that one company had the possibility to rate different application systems (i. e. Collaborative, Content Management, ERM, Human Capital, SCM, Operations \& Manufacturing, Engineering, CRM applications) with regard to the applicability and drivers of SaaS-adoption. If a company rated several application types, it had to fill out the entire survey for each single application type. The questionnaire was addressed to top or senior IT executives. After 45 responses were dropped due to missing data, a total of 374 usable responses from 297 different companies could be used for analyzing our model. This low response rate is a common problem in the IS area, as it reflects the challenges in obtaining responses from top management.

\subsection{Operationalization of constructs}

Tab. 1 shows the operationalization of variables of our conceptual model. Measurement items of all variables were drawn from those of previous studies. Except one question, for which a percentage estimate on the SaaS adoption rate in 2008 and 2010 was requested, all other questions were rated on a scale ranging from 1 to 7 , with 1 referring to the lowest score and 7 the highest score in the item scale. For attitude toward SaaS-adoption and subjective norm, we adopted the semantic differential approach and used three bi-polar dimensions (negative-positive, harmful-beneficial, unimportant-important) on a 7-point scale (Ajzen and Fishbein 1980). The order of the questions in the questionnaire was randomly assigned to prevent order bias and halo effects from confounding the results (Kervin 1992).

\subsection{Instrument validation}

Content validity was established through the adoption of constructs that had been used in former studies (see Tab. 1) and through pilot tests with IS practitioners 
of different industries. The reflective measurement models of the total and application specific models were validated using the standard procedures of current literature (Chin 1998; Straub 1989). Items of scales in a related domain were pooled and factor-analyzed to assess their convergent and discriminant validity. While convergent validity was determined both at the individual indicator level and at the specified construct level, discriminant validity was assessed by analyzing the average variance extracted and interconstruct correlations. The results are illustrated in Tab. 2.

All standardized factor loadings of the overall and application-specific models are significant (at least at the $\mathrm{p}<0.05$ level), thus suggesting convergent validity (Bagozzi et al. 1991). To evaluate construct reliability, we calculated composite reliability for each construct. All constructs have a composite reliability significantly above the cutoff value of 0.70 (Hair et al. 1998). All reflective constructs also met the threshold value for the average variance extracted (AVE $>0.50)$. For discriminant validity of latent variables, the square roots of AVEs exceeded the interconstruct correlations that were negligibly low between the independent constructs. Thus, constructs in our measurement model satisfy various reliability and validity criteria, and could be used to test the structural models and the associated hypotheses proposed earlier.

\section{Empirical analysis}

In the next two sections, the empirical results of our analysis will be presented. First, the drivers of SaaS-adoption of individual application types will be presented. Second, SaaS-adoption will be analyzed from an aggregate point of view across all application types. We tested our model on SaaS-adoption by using PLS-based structural equation modeling (Chin 1998; Lohmöller 1989). In contrast to parameteroriented and covariance-based structural equation modeling, the component-based PLS method is prediction-oriented (Chin 1998). It seeks to predict the variations in the dependent variables of the model, which we want to achieve for the SaaSbased outsourcing construct in our study. More specifically, PLS uses an iterative algorithm of ordinary least square regressions that seeks to minimize the residual

\begin{tabular}{|c|c|c|c|c|}
\hline Constructs & $\begin{array}{l}\text { Number of } \\
\text { indicators }\end{array}$ & $\begin{array}{l}\text { Range of stan- } \\
\text { dardized factor } \\
\text { loadings* }\end{array}$ & $\begin{array}{l}\text { Composite reli- } \\
\text { ability } \\
\left(\rho_{c}\right)^{* * *}\end{array}$ & $\begin{array}{l}\text { Average variance } \\
\text { extracted (AVE) }\end{array}$ \\
\hline SaaS-adoption & 2 & $0.767-0.843$ & $0.846-0.856$ & $0.867-0.880$ \\
\hline $\begin{array}{l}\text { Attitude toward } \\
\text { SaaS-adoption }\end{array}$ & 3 & $0.939-0.976$ & $0.969-0.973$ & $0.913-0.924$ \\
\hline Subjective norm & 3 & $0.940-0.981$ & $0.985-0.974$ & $0.926-0.957$ \\
\hline $\begin{array}{l}\text { Application } \\
\text { specificity }\end{array}$ & 3 & $0.710-0.983$ & $0.747-0.858$ & $0.501-0.670$ \\
\hline $\begin{array}{l}\text { Perceived adop- } \\
\text { tion uncertainty }\end{array}$ & 3 & $0.828-0.950$ & $0.904-0.963$ & $0.760-0.897$ \\
\hline Strategic value & 3 & $0.898-0.993$ & $0.940-0.994$ & $0.838-0.982$ \\
\hline $\begin{array}{l}\text { Application } \\
\text { inimitability }\end{array}$ & 3 & $0.734-0.969$ & $0.747-0.879$ & $0.687-0.720$ \\
\hline
\end{tabular}

\begin{tabular}{|c|c|c|c|}
\hline Application characteristics & $\begin{array}{l}\text { Office }(n=75) \\
\text { Mean } \\
\text { (St. Dev.) }\end{array}$ & $\begin{array}{l}\text { CRM ( } n=61) \\
\text { Mean } \\
\text { (St. Dev.) }\end{array}$ & $\begin{array}{l}\text { ERP }(n=74) \\
\text { Mean } \\
\text { (St. Dev.) }\end{array}$ \\
\hline Application specificity & $3.39(0.90)$ & $3.87(0.88)$ & $4.88(0.95)$ \\
\hline $\begin{array}{l}\text { Perceived adoption } \\
\text { uncertainty }\end{array}$ & $2.41(1.67)$ & $3.96(1.28)$ & $5.54(1.13)$ \\
\hline Strategic value & $2.60(1.98)$ & $4.15(1.31)$ & $5.86(1.12)$ \\
\hline Application inimitability & $2.71(0.99)$ & $3.03(2.64)$ & $4.47(2.53)$ \\
\hline
\end{tabular}

variances of the dependent latent variables and all the reflective indicators (Wold 1989). Since PLS does not account for the covariances of all indicators, but only for those variances that have been specified in the model, it is closer to the actual data than the covariance-based procedure (Fornell 1989). Due to the partial estimation of single elements in the causal model, fewer empirical cases are needed in PLS- than in covariance-based structural equation modeling to generate consistent and reliable results (Chin and Newsted 1999). To provide an aggregate view on the assessment of PLS-based models, the structural model is evaluated by looking at the percentage of the variance explained $\left(\mathrm{R}^{2}\right)$ of all dependent latent variables. By examining the size and stability of the coefficients associated with the paths between latent variables with bootstrapping sampling (Bollen and Stine 1993), hypotheses, which were proposed during the model specification process, are finally analyzed for their significance.

\subsection{Results on SaaS-adoption of individual application types}

In order to gain a thorough understanding of how SaaS-adoption drivers influence the outsourcing decision, we first assessed the differences between Office, CRM, and ERP systems. We selected these three application types, as they turned out to cover the end- and midpoints of continuums regarding application specificity, adoption uncertainty, strategic significance, and application inimitability allowing a comprehensive view on distinctive application types (see Tab. 3).

Office applications were rated as having a relatively low level of specificity, strategic significance, and inimitability. Furthermore, adopting Office applications in a SaaS-based relationship was rated as being associated with a comparatively low level of uncertainty. On the contrary, ERP systems were rated highest in all four categories, while CRM system covered the middle ground. A MANOVA analysis showed that the differences in the means of the four application characteristics between Office, CRM, and ERP applications were also statistically significant on the $\mathrm{p}<0.001$ level 


\begin{tabular}{|c|c|c|c|c|c|c|}
\hline \multirow{2}{*}{$\begin{array}{l}\text { Application } \\
\text { character- } \\
\text { istics }\end{array}$} & \multicolumn{2}{|c|}{ Office $(n=75)$} & \multicolumn{2}{|l|}{ CRM $(n=61)$} & \multicolumn{2}{|l|}{$\operatorname{ERP}(n=74)$} \\
\hline & $\begin{array}{l}\text { Attitude } \\
\text { SaaS-adop- } \\
\text { tion } \\
\left(\mathrm{R}^{2}=0.81\right)\end{array}$ & $\begin{array}{l}\text { SaaS-adop- } \\
\text { tion } \\
\left(R^{2}=0.55\right)\end{array}$ & $\begin{array}{l}\text { Attitude } \\
\text { SaaS-adop- } \\
\text { tion } \\
\left(\mathrm{R}^{2}=0.68\right)\end{array}$ & $\begin{array}{l}\text { Attitude } \\
\text { SaaS-adop- } \\
\text { tion } \\
\left(\mathrm{R}^{2}=0.81\right)\end{array}$ & $\begin{array}{l}\text { SaaS-adop- } \\
\text { tion } \\
\left(R^{2}=0.55\right)\end{array}$ & $\begin{array}{l}\text { Attitude } \\
\text { SaaS-adop- } \\
\text { tion } \\
\left(\mathrm{R}^{2}=0.68\right)\end{array}$ \\
\hline $\begin{array}{l}\text { Attitude } \\
\text { toward } \\
\text { SaaS-adoption }\end{array}$ & - & $0.24^{* *}$ & - & 0.13 & - & $0.60^{* * *}$ \\
\hline $\begin{array}{l}\text { Subjective } \\
\text { norm }\end{array}$ & $0.93^{* * *}$ & 0.15 & $0.75^{* * *}$ & 0.05 & $0.35^{* * *}$ & 0.03 \\
\hline $\begin{array}{l}\text { Application } \\
\text { specificity }\end{array}$ & $-0.30^{* * *}$ & -0.03 & -0.11 & -0.20 & -0.04 & -0.07 \\
\hline $\begin{array}{l}\text { Perceived } \\
\text { adoption } \\
\text { uncertainty }\end{array}$ & $-0.18^{*}$ & $-0.27^{* *}$ & -0.07 & $-0.48^{* * *}$ & $-0.29^{* *}$ & -0.09 \\
\hline $\begin{array}{l}\text { Strategic } \\
\text { significance }\end{array}$ & -0.01 & -0.05 & $-0.26^{* *}$ & $-0.53^{* * *}$ & $-0.14^{* *}$ & $-0.17^{*}$ \\
\hline $\begin{array}{l}\text { Application } \\
\text { inimitability }\end{array}$ & -0.02 & -0.16 & -0.10 & -0.11 & $-0.27^{* * *}$ & -0.08 \\
\hline \multicolumn{7}{|c|}{${ }^{*} p<0.05 ;{ }^{* *} p<0.01 ;{ }^{* * *} p<0.001$} \\
\hline
\end{tabular}

\begin{tabular}{|c|c|c|c|c|}
\hline \multirow[b]{2}{*}{ Application type } & \multicolumn{2}{|c|}{$\begin{array}{l}\text { Adoption levels of SMBs } \\
\text { (\% of respective IT application } \\
\text { budget) }\end{array}$} & \multicolumn{2}{|c|}{$\begin{array}{l}\text { Adoption levels of large enterprises } \\
\text { (\% of respective IT application } \\
\text { budget) }\end{array}$} \\
\hline & 2008 & 2010 & 2008 & 2010 \\
\hline Collaboration & $10 \%$ & $35 \%$ & $13 \%$ & $43 \%$ \\
\hline $\begin{array}{l}\text { Content } \\
\text { Management }\end{array}$ & $6 \%$ & $25 \%$ & $17 \%$ & $36 \%$ \\
\hline Office & $6 \%$ & $23 \%$ & $9 \%$ & $28 \%$ \\
\hline CRM & $5 \%$ & $32 \%$ & $15 \%$ & $37 \%$ \\
\hline Human Relations & $3 \%$ & $19 \%$ & $7 \%$ & $23 \%$ \\
\hline $\begin{array}{l}\text { Business } \\
\text { Intelligence }\end{array}$ & $3 \%$ & $17 \%$ & $1 \%$ & $11 \%$ \\
\hline ERP & $3 \%$ & $10 \%$ & $1 \%$ & $10 \%$ \\
\hline SCM & $0 \%$ & $2 \%$ & $0 \%$ & $1 \%$ \\
\hline Production & $0 \%$ & $0 \%$ & $3 \%$ & $4 \%$ \\
\hline Engineering & $0 \%$ & $3 \%$ & $0 \%$ & $4 \%$ \\
\hline Total average & $5 \%$ & $21 \%$ & $6 \%$ & $23 \%$ \\
\hline
\end{tabular}

$\left(\right.$ F-value $_{\text {Specificity }}=13.3(\mathrm{p}<0.001)$;

F-value $_{\text {Uncertainty }}=24.20(\mathrm{p}<0.001)$;

F-value $_{\text {StrategicValue }}=26.84(\mathrm{p}<0.001)$;

F-value $\left._{\text {Inimitability }}=2.59(\mathrm{p}<0.05)\right)$.

In a second step and based on these three sub-samples, individual structural equation models were examined. Standardized path coefficients and the share of explained variance $\left(\mathrm{R}^{2}\right)$ are shown in Tab. 4 . In the Office sample, five significant paths could be identified. Subjective norm showed a considerably strong and positive impact on the attitude toward SaaS-adoption that was also significantly, albeit to a lesser degree, affected by application specificity and adoption uncertainty. The level of
SaaS-adoption, in turn, was significantly explained by the attitude toward SaaSadoption and adoption uncertainty. In the CRM sample, four relationships between exogenous and endogenous variables were significant. Once again, subjective norm was a significant predictor of the attitude toward SaaS-adoption. Moreover, we found that strategic value significantly influenced SaaS-adoption both directly and indirectly via the attitude toward SaaS-adoption. Finally, adoption uncertainty also contributed strongly and significantly to the explanation of SaaS-adoption. SaaS-adoption in the application area of ERP had the highest number of significant paths. Subjective norm, adoption uncertainty, strategic value, and application inimitability were strongly associated with the attitude toward SaaS-adoption. SaaS-adoption itself was explained significantly just by two factors, namely the attitude toward SaaS-adoption and strategic value.

In all three sub-models, a higher share of variance in the attitude toward SaaSadoption than in the level of SaaS-adoption could be explained. Having $\mathrm{R}^{2} \mathrm{~s}$ exceeding $40 \%$ in all sub-models, the theories taken to inform us on SaaS-adoption appear to be highly relevant. Overall, it can be ascertained that transaction cost theory dominates in the prediction of SaaS-adoption in application areas with low levels of specificity, strategic value, and adoption uncertainty (such as Office, but also Collaboration). On the other hand, the resourcebased theory lends itself better to explain SaaS-adoption in application markets with a higher level of specificity, strategic value, and adoption uncertainty (such as CRM and ERP). The three most outstanding predictors of SaaS-adoption are attitude toward SaaS-adoption, strategic value, and adoption uncertainty. All three variables were significant drivers in the majority of application areas. By contrast, application specificity and inimitability were more inconsistent in predicting SaaS-adoption. Finally, comparing all three theoretical angles, the theory of planned behavior stood out as being the most consistent theoretical foundation to explain the attitude toward SaaS-adoption and SaaS-adoption itself.

\subsection{Results on SaaS-adoption across all application types}

To get a more general and representative perspective on the drivers of SaaS-adoption, we examined our research model across all application types. As several authors in the IS literature have proposed that it is more likely that smaller and midsized businesses will take advantage of SaaS-adoption than large enterprises, we analyzed SaaS-adoption levels in 2008 and 2010 for both adopter groups (see Tab. 5).

SMBs, defined as having less than 250 employees (European Commission 2003), allotted around $5 \%$ of their IT application budget to SaaS-based outsourcing in 2008 overall and plan to spend as much as $21 \%$ in 2010 . By comparison, large enterprises with more than 250 employ- 


\section{COMMERZBANK}

\section{The best answer to growing challenges is growing performance.}

Commerzbank and Dresdner Bank are now one bank.

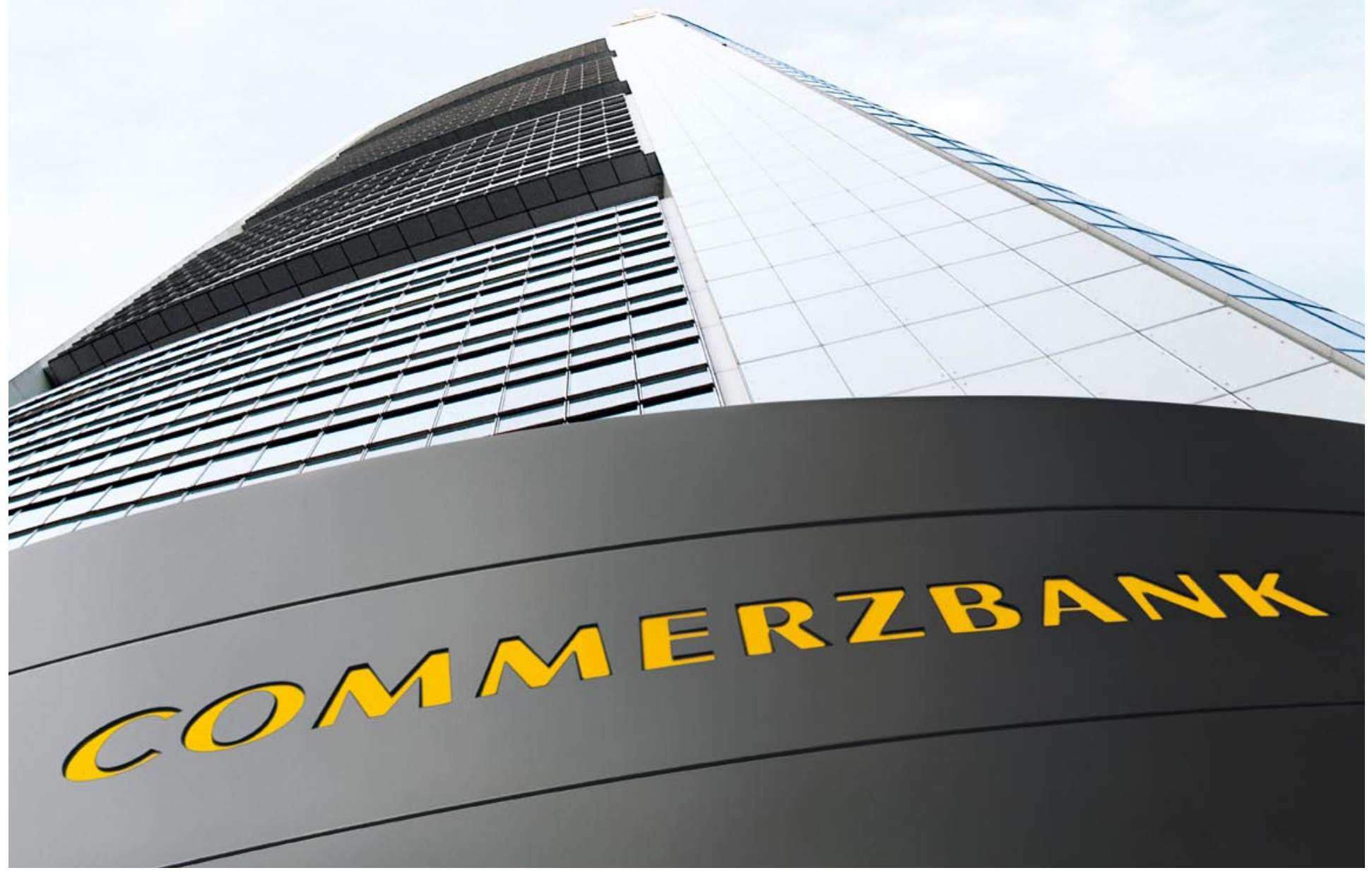

The combination of Commerzbank and Dresdner Bank created a new market leader in the German private and corporate sector. The new Commerzbank offers the experience and benefits of two major banks - also internationally. We will continue expanding our position as Germany's key bank for export financing. And for foreign companies we will become the first contact in all business related activities in Germany.

Together we accept responsibility as being a strong bank and reliable partner for our clients. 


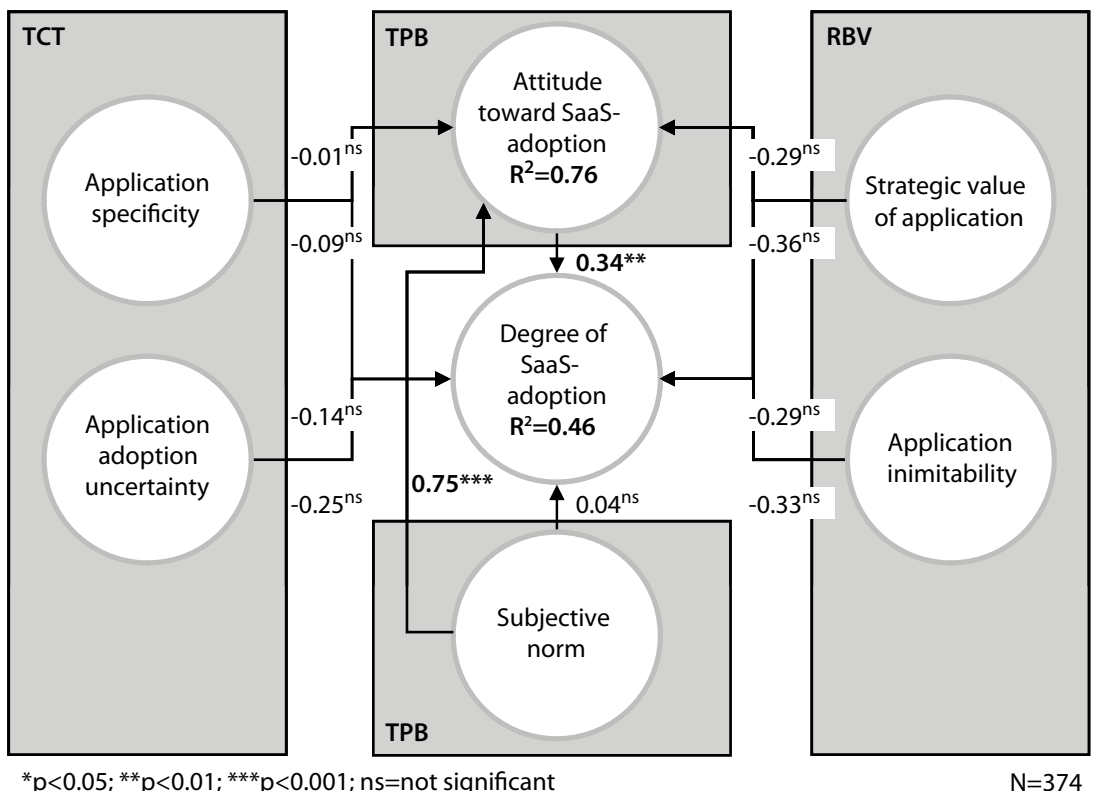

Fig. 2 Results of the overall model

ees allocated around $6 \%$ of their IT application budget to SaaS-based sourcing models in 2008 and predicted to spend as much as $23 \%$ in SaaS in 2010. Interestingly, actual and planned adoption levels of large enterprises tend to be higher than of SMBs. However, comparing the absolute adoption levels between SMBs and large enterprises in 2008 and 2010 along all applications revealed that the differences in the adoption levels in our samples were not significant. Consequently, it can be stated that, at least in our random sample, SaaS-based applications are not adopted more by SMBs than by larger enterprises. According to the statements of potential user companies, Collaboration (e. g. e-mail), Content Management, Office, and CRM are application types with highest current and future SaaSadoption rates, while ERP, SCM, and Production/ Engineering systems are adopted only hesitantly in the present. Regarding the growth rates of SaaS-adoption in the area of ERP systems in the next years, however, the outlook for core applications appears to be promising.

Examining our hypothesized research model yielded the standardized path coefficients and $\mathrm{R}^{2}$ as major model-fit index as shown in Fig. 2. The degree of (planned) SaaS-adoption in 2010 was taken as dependent variable allowing IT providers to influence future SaaS-adoption behavior by manipulating adoption drivers.

While factors derived from transaction cost theory and resource-based view are not significant drivers on the overall level, factors stemming from theory of planned behavior showed strong explanatory power. Subjective norm has a very strong and highly significant impact on the attitude toward SaaS-adoption that, in turn, affects SaaS-adoption significantly. Obviously, the opinion of (trusted) third parties on SaaS plays a major role in forming the attitude of companies considering the adoption of SaaS. However, companies appear not to blindly follow the recommendations of other organizations by unreflectively imitating their behavior. Instead, the opinions of third parties seem to inform in the IT user companies' process of building their own attitude about SaaS based on criteria such as costs, benefits, and investments. In total, around $76 \%$ of the variance of the attitude toward SaaS-adoption and $46 \%$ of SaaSadoption could be explained by the factors under investigation which represents a considerable share of total variance.

\section{Discussion}

\subsection{Major findings and interpretations}

Finding 1: The patterns of decisions on SaaS-adoption vary between application types. IT vendors should address these application-specific drivers to be more successful in converting IT user companies to SaaS-customers.
As shown in our statistical analyses, the drivers for adopting SaaS vary depending on the characteristics of the application that is considered for SaaS-outsourcing. Applications that can be characterized as less specific (i. e. high level of standardization), less strategic relevant (i. e. supporting less critical parts of the company), and that are associated with a lower level of adoption uncertainty (i. e. companies bear lower technical and economic risks when outsourcing this application type) are to a higher degree adopted in a SaaS-based setting. For that reason, Office and Collaboration applications with lower levels of specificity, strategic significance, and adoption uncertainty had the highest adoption rates in 2008 and 2010. By contrast, ERP systems with higher levels of specificity, strategic significance, and adoption uncertainty rank among the applications with the lowest SaaS-adoption rates.

SaaS-providers can learn three things from these findings. First, when choosing which applications should be offered in a SaaS-based mode, they should put an emphasis on software that is easy to standardize and that does not support functions which are at the very core of a company's processes. Apparently, IT user companies are still skeptical about the fact that SaaS entails storing more or less critical company data on the provider side which would hinder SaaS-clients from directly accessing their data in the case of a network break-down. Second, even though IT user companies do not unreflectively follow the recommendations of influential third parties without thoroughly evaluating the options based on criteria such as IS costs and resources, their attitude toward SaaS appears to be influenced considerably by expert opinions and peer pressure. SaaS-providers should therefore engage in targeting opinion-leaders and third-parties (e. g. in associations, and lobbies) who have a say in the assessment of new technologies. For example, they could offer their SaaS solution to influential opinion leaders for free with the aim to initiate a chain reaction. Third, individual levers exist for fostering the adoption of SaaS in different application markets. IT user companies evaluating the adoption of SaaS-based office applications should be addressed by SaaS-providers through mitigating technical and economic risks associated with a SaaS-based relationship. One possible approach could be to inte- 
grate risk-mitigating features into contractual modalities (e. g. liability clauses or concrete SLA specifications) that would increase trust and decrease opportunistic behavior on both sides of the SaaS-relationship. SaaS-providers targeting companies that assess SaaS for CRM or ERP systems should aim at positioning themselves as strategic partner guaranteeing their clients that their applications will remain a strategic and inimitable factor in the fulfillment of company and customer needs.

Finding 2: Classical economic and strategic theories on IT outsourcing should be complemented by behavioral theories to yield better and more general explanations of IT adoption.

Classical economic and strategic theories on IT outsourcing turned out to be relevant only for specific application types, but had no significant explanatory power across application types. This result is not in line with previous studies that found that asset specificity, uncertainty, and strategic value are indeed significant factors of IT outsourcing. One explanation of this divergence could be that SaaS is an immature and therefore still intangible software delivery model. It may thus be too early to provide homogeneous answers to SaaS-adoption regarding application specificity, adoption uncertainty, or strategic value across application types. Our empirical study showed that transaction cost theoretical thinking is especially important in the SaaS-based sourcing of applications of lower specificity and strategic significance (such as Office), whereas the resource-based view turned out to be a valid theoretical approach to explain the adoption of applications of higher specificity and strategic significance (such as CRM and ERP). Surprisingly, we found that theoretical concepts derived from behavioral theories yielded the most consistent results across application types. As a consequence, researchers examining (on-demand) application sourcing behavior of companies on a more general level should include factors of behavioral theories to increase the explanatory power of their models. The findings and recommendations of this study also support the logic underlying existing technology acceptance models that have already integrated behavioral aspects into the explanation of IT adoption and sourcing.

Finding 3: Firm size does not matter in SaaS-adoption.
In terms of firm size as a factor influencing the level of SaaS-adoption, we could find that organizational size had no significant impact both in the full and in the various sub-samples. These results are not in sync with the propositions made by previous research studies (Kern et al. 2002a) that smaller and medium-sized firms are generally more prone to adopt ondemand outsourcing options for obtaining fast access to valuable IT resources and capabilities. On the contrary, our research findings show that large enterprises are at least equally inclined to adopt SaaS in all relevant application markets. Against the predictions of many IT vendors and IT consulting companies, SaaS-based outsourcing is not only targeted at SMBs, but also a valid sourcing option for larger corporations. SaaS-providers should thus not neglect large enterprises when promoting their SaaS offerings. Otherwise, considerable revenue potential may be foregone up-front.

\subsection{Limitations and future research}

Although the findings above demonstrate the usefulness and relevance of the three theoretical frameworks for assessing SaaS-adoption, we believe that there are several key limitations of our study. First, since our dataset is cross-sectional in nature, we can only show associations, not causality. In the same regard, measuring SaaS-adoption by estimated SaaS-adoption rates in 2010 may be an insufficient proxy for studying longitudinal processes and to uncover time preferences in the adoption behavior of companies. Second, the investigation of SaaS-adoption on the application level turned out to be a relevant approach to gain concrete insights into different application markets. However, restricting our analysis to Germany may fall short of providing a representative picture on SaaS-adoption in a global world. Future research should thus replicate this research design in other relevant countries. With regard to the theoretical framework we have applied and the empirical findings we have gained, we can derive four further recommendations for future research. First, as has already happened before in traditional IT outsourcing studies, extending our theoretical framework to other theories (e. g. agency cost theory, opinion-leader theory) would add further insights into the drivers and barriers of the adoption of SaaS. In particular, the com- parison of the explanatory power of rather classical economic and strategic theories with behavioral theories from social sciences would contribute valuable epistemological as well as ontological questions to IS research. Second, as subjective norm, attitude toward SaaS-adoption, adoption uncertainty, and strategic value stood out as main factors affecting SaaS-adoption, deepening the notions of these factors within a larger nomological network would add more insights for researchers as well as practitioners. Third, the potential for common method variance may exist because measurements of all of the constructs in this study were collected at the same point in time and via the same instrument (Straub and Limayen 1995). To test common method bias, we applied Harmon's one-factor test to the data from our survey (Podsakoff et al. 2003). We performed an exploratory factor analysis on all the variables, but no single factor was observed and no single factor accounted for a majority of the covariance in the variables, suggesting that common method bias is not a concern in the present study. Future studies should nonetheless attempt to use multiple and cross-checked sources of data to mitigate common method bias problems at an early stage of research. Last but not least, we used a key informant method for data collection. This method, while having its advantages, also suffers from the limitations that the data reflects the opinion of one person. Although our data represents the perceptions of relatively senior IS executives who are most likely able to assess technology adoption in their company, we recommend that future studies consider research designs that allow data collection from multiple relevant stakeholders (e. g. IS purchasing managers and end-users) within an organization.

\section{References}

Ahmed E, Paul L (2004) Negotiating in serviceoriented environments. Communications of the ACM 47(8):103-108

Ajzen I (1991) The theory of planned behavior. Organizational Behavior \& Human Decision Processes 50(3):179-211

Ajzen I, Fishbein M (1980) Understanding attitudes and predicting social behavior. Prentice Hall, Englewood Cliffs

Arrow KJ (1969) The organization of economic activity: Issues pertinent to the choice of market versus non-market allocation. In: The ana- 


\section{Abstract}

Alexander Benlian, Thomas Hess, Peter Buxmann

\section{Drivers of SaaS-Adoption - An Empirical Study of Different Application Types}

Software-as-a-Service (SaaS) is said to become an important cornerstone of the Internet of Services. However, while some market research and IT provider firms fervently support this point of view, others already conjure up the failure of this on-demand sourcing option. Oftentimes based on weak empirical data and shaky reasoning, these inconsistent perspectives lack scientific rigor and neglect to present a more differentiated picture of SaaS-adoption. This study seeks to deepen the understanding of factors driving the adoption of Software-as-aService (SaaS). Grounded in transaction cost theory, the resource-based view, and the theory of planned behavior, we develop a research model to assess SaaS-adoption at the application level. Survey data of 297 firms in Germany with 374 valid response items across different industries were collected to test the theoretical model. Our analysis revealed that patterns on the decision on SaaS-adoption differ across application types. Social influence, attitude toward SaaS-adoption, adoption uncertainty, and strategic value turned out to be the strongest and most consistent drivers across all application types. Furthermore, we found that firm size does not matter in SaaS-adoption, since large enterprises and small-and medium-sized companies had similar adoption rates. Overall, this study provides relevant findings that IT vendors can use to better appeal to potential companies that consider adopting SaaS.

Keywords: Software-as-a-service, IT sourcing, Adoption, Transaction-cost theory, Resource-based view, Theory of planned behavior lysis and evaluation of public expenditure: The PPB system. U.S. Government Printing Office, Washington, DC, pp 39-73

Aubert BA, Rivard S, Patry M (2004) A transaction cost model of IT outsourcing. Information and Management 41(7):921-932

Bagozzi RP, Yi Y, Phillips LW (1991) Assessing construct validity in organizational research. Administrative Science Quarterly 36(3):421-458

Barney J (1991) Firm resources and sustained competitive advantage. Journal of Management 17(1):99-120

Benlian A (2009) A transaction cost theoretical analysis of Software-as-a-Service (SaaS)-based sourcing in SMBs and enterprises. In: Proceedings of the $17^{\text {th }}$ European conference on information systems, Verona

Benlian A, Hess T (2009) Welche Treiber lassen SaaS auch in Großunternehmen zum Erfolg werden? Eine empirische Analyse der SaaS-Adoption auf Basis der Transaktionskostentheorie. In: Proceedings of the $9^{\text {th }}$ international conference Wirtschaftsinformatik (Volume 1), Vienna

Blumenberg S, Beimborn D, König W (2008) Determinants of IT outsourcing relationships: a conceptual model. In: Proceedings of the 41th Hawaii international conference on system sciences, Waikoloa

Bollen KA, Stine RA (1993) Bootstrapping goodness-of-fit measures in structural equation models. In: Bollen KA, Long JS (eds) Testing structural equation model. Sage, Newbury Park, pp 111-135

Brandt B, Buxmann P (2008) Chancen und Risiken des Einsatzes von Software as a Service in mittelständischen Unternehmen - Ergebnisse einer leitfadengestützten Expertenbefragung (BITKOM 2008). In: Innovationen im Outsourcing - Wie Unternehmen von Innovationspartnerschaften mit Service-Anbietern profitieren können, Elztal

Buxmann P, Hess T, Lehmann S (2008) Software as a service. WIRTSCHAFTSINFORMATIK 50(6):500-503

Chin WW (1998) The partial least squares approach for structural equation modelling. In: Marcoulides GA (ed) Modern methods for business research. Lawrence Erlbaum Associates, Hillsdale, pp 295-336

Chin WW, Newsted PR (1999) Structural equation modeling analysis with small samples using partial least squares. In: Hoyle RH (ed) Statistical strategies for small sample research. SAGE, Thousand Oaks, pp 307-341

Choudhary V (2007) Comparison of software quality under perpetual licensing and software as a service. Journal of Management Information Systems 24(2):141-165

Chung J-Y, Lin K-J, Mathieu RG (2003) Web services computing: advancing software interoperability. Computer 36(10):35-37

Clemons EK, Row MC (1991) Sustaining IT advantage: The role of structural differences. MIS Quarterly 15(3):275-292

Coase RH (1937) The nature of the firm. Economica 4(16):386-405

Davis FD (1989) Perceived usefulness, perceived ease of use, and user acceptance of information technology. MIS Quarterly 13(3):319-339

Dibbern J (2004) Sourcing of application software services. Empirical evidence of cultural, industry and functional differences. Physica, Heidelberg

Dibbern J, Chin WW, Heinzl A (2005) The impact of human asset specificity on the sourcing of application services. In: Proceedings of the $13^{\text {th }}$ European conference of information systems, Regensburg

Dibbern J, Goles T, Hirschheim R, Jayatilaka B (2004) Information systems outsourcing: a survey and analysis of the literature. ACM SIGMIS Database 35(4):6-102

Erl T (2006) Service-oriented architecture: concept, technology, and design. Prentice Hall, Upper Saddle River

European Commission (2003) Recommendation 2003/361/EC: SME definition. http://ec.europa. eu/enterprise/enterprise_policy/sme_definition/index_en.htm. Accessed 2008-06-30

Fornell C (1989) The blending of theoretical and empirical knowledge in structural equations with unobservables. In: Wold $\mathrm{H}$ (ed) Theoretical empiricism: A general rationale for scientific model-building. Paragon House, New York, pp 153-173

Gonzalez R, Gasco J, Llopis J (2006) Information systems outsourcing: A literature analysis. Information \& Management 43(7):821-834

Hair JF, Anderson RE, Tatham RL, Black WC (1998) Multivariate data analysis with readings. Prentice Hall, Englewood Cliffs

Hall M (2008) On the mark: SaaS slips past IT's final barrier. http://www.computerworld.com/ action/article.do?command=viewArticleBasic\& articleld=316501. Accessed 2008-07-15

Jung J, Bube L (2008) Software as a Service wird kollabieren. http://www.networkcomputing. de/software-as-a-service-wird-kollabieren/. Accessed 2008-09-13

Kern T, Kreijger J, Willcocks L (2002a) Exploring ASP as sourcing strategy: theoretical perspectives, propositions for practice. Journal of Strategic Information Systems 11(2):153-177

Kern T, Lacity MC, Willcocks L (2002b) Netsourcing: renting business applications and services over a network. Prentice-Hall, New York

Kervin JB (1992) Methods for business research. Harper Collins, Toronto

Kishore R, Rao HR, Swinarski ME (2001) Impact of ASP capabilities on application service quality. In: Proceedings of the $7^{\text {th }}$ Americas conference on information systems, Boston

Lacity MC, Hirschheim R (1995) Beyond the information systems outsourcing bandwagon: the insourcing response. Wiley, Chichester

Loh L (1994) An organizational-economic blueprint for information technology outsourcing: concepts and evidence. In: Proceedings of the $15^{\text {th }}$ international conference on information systems, Vancouver

Loh L, Venkatraman N (1995) An empirical study of information technology outsourcing: benefits, risks, and performance implications. In: Proceedings of the $16^{\text {th }}$ international conference on information systems, Amsterdam 
Lohmöller JB (1989) Latent variable path modeling with partial least squares. Physica, Heidelberg

Lünendonk T (2007) Führende Standard-Software-Unternehmen in Deutschland. Studie der Lünendonk $\mathrm{GmbH}$

Ma Q, Pearson JM, Tadisina S (2005) An exploratory study into factors of service quality for application service providers. Information \& Management 42(8):1067-1080

Nam K, Rajagopalan S, Rao HR, Chaudhury A (1996) A two-level investigation of information systems outsourcing. Communications of the ACM 39(7):37-44

Nüttgens M, Iskender D (2008) Geschäftsmodelle für dienstebasierte Informationssysteme - Ein strategischer Ansatz zur Vermarktung von Webservices. WIRTSCHAFTSINFORMATIK 50(1):31-38

Ouchi WG (1980) Markets, bureaucracies, and clans. Administrative Science Quarterly 25(1):129-141

Pearl B (2004) The software customer/supplier relationship. Communications of the ACM 47(2):77-81

Penrose ET (1959) The theory of the growth of the firm. Blackwell, New York

Peteraf M (1993) The cornerstones of competitive advantage: a resource-based view. Strategic Management Journal 14(3):179-191

Peterson RR, Fairchild AM (2003) Adoption trends in application service provisioning: an exploratory field study of small and medium-sized enterprises. In: Proceedings of the European conference on information systems, Naples

Pettey C (2006) Gartner says 25 percent of new business software will be delivered as software as a service by 2011. http://www.gartner.com/ it/page.jsp?id=496886. Accessed 2008-08-30

Picot A, Dietl H, Franck E (2005) Organisation. Eine ökonomische Perspektive. Schäffer-Poeschel, Stuttgart

Podsakoff PM, Mackenzie SB, Lee J, Podsakoff NP (2003) Common method biases in behavioral research: A critical review of the literature and recommended remedies. Journal of Applied Psychology 88(5):879-903

Porter ME, Millar VE (1985) How information gives you competitive advantage. Harvard Business Review 63(4):149-160

Prehl S (2008) Software as a Service erreicht Europa. http://www.computerwoche.de/knowledge_center/it_services/1870304/. Accessed 2008-06-30

Rai A, Sambamurthy V (2006) The growth of interest in services management: opportunities for information systems scholars. Information Systems Research 17(4):327-331

Rogers EM (1962) Diffusion of innovations. The Free Press, New York

Seltsikas P, Currie WL (2002) Evaluating the application service provider (ASP) business model: the challenge of integration. In: Proceedings of the $35^{\text {th }}$ Hawaii international conference on system science, Hawaii

Smith MA, Kumar RL (2004) A theory of application service provider (ASP) use from a client perspective. Information \& Management
41(8):977-1002

Straub D (1989) Validating instruments in MIS research. MIS Quartely 13(2):147-169

Straub D, Limayen M (1995) Measuring system usage: implications for IS theory testing. Management Science 41 1328-1343

Teng JTC, Cheon MJ, Grover V (1995) Decisions to outsource information systems functions: Testing a strategy-theoretic discrepancy model. Decision Sciences 26(1):75-103

Valente P, Mitra G (2007) The evolution of webbased optimisation: From ASP to e-Services. Decision Support Systems 43(4):1096-1116

Walsh KR (2003) Analyzing the application ASP concept: technologies, economies, and strategies. Communications of the ACM 46(8):103107

Waters B (2005) Software as a service: A look at the customer benefits. Journal of Digital Asset Management 1(1):32-39

Wernerfelt B (1984) A resource-based view of the firm. Strategic Management Journal 5(2):171180

Wiener M (2006) Critical success factors of offshore software development projects -the perspective of German-speaking companies. Gabler, Wiesbaden

Williamson OE (1985) The economic institutions of capitalism: firms, markets, relational contracting. The Free Press, New York

Williamson OE (1991) Comparative economic organization: The analysis of discrete structural alternatives. Administrative Science Quarterly 36(2):269-296

Wold $\mathrm{H}$ (1989) Introduction to the second generation of multivariate analysis. In: Wold $\mathrm{H}$ (ed) Theoretical empiricism: A general rationale for scientific model-building. Paragon, New York, pp vii-xl

Zencke P, Eichin R (2008) SAP Business By Design - Die neue Mittelstandslösung der SAP. WIRTSCHAFTSINFORMATIK 50(1):47-51 